\title{
ATTITUDES AND EXPERIENCES OF CLASSROOM SCIENCE: CHILDREN'S VOICES
}

\author{
Gillian Ward \\ Lauren E Donnan \\ Kirsten McNabb \\ New Zealand, University of Auckland \\ g.ward@auckland.ac.nz
}

First draft received: 30 April $2016 \quad$ Final proof received: 30 August 2016

Abstract
This article draws on two studies that examined primary children's attitudes towards science in the
classroom and their experiences of science. Through the data drawn from semi-structured interviews, it
was evident that the children were mostly positive about science, but their experiences of science in the
classroom were not always how they would prefer their science learning to proceed. The findings
highlight aspects of their experiences that enhanced or detracted from their interest in science. In
particular, the students stated the importance of being taught relevant and meaningful science in a
collaborative context. Children's out-of-school contexts also became important in their learning of
science. These findings are discussed, and suggestions are made for ways in which teachers can make
changes to their planning and teaching in order to support positive attitudes to science within the
classroom.
Keywords: Attitudes towards science, children's voice, elementary education, primary education
To cite this paper (in APA style):
Ward, G., Donnan, L. E., \& McNabb, K. (2016). Attitudes and experiences of classroom science:
Children's voices. International Journal of Education, $9(1), 10-16$. doi:
dx.doi.org/10.17509/ije.v9i1.3712

\section{INTRODUCTION}

Science is relevant to everyone, as it has a profound impact on everyone's daily lives and therefore, the teaching and learning of science is of substantial importance for all people (OECD, 2007; Osborne, 2007). The purpose of science education is two-fold: one is to provide children with knowledge in the science disciplines so they can pursue science at a tertiary level and as a career (OECD, 2008; Osborne, 2007). The second purpose is to develop students' scientific literacy so that they can participate as citizens who have an understanding of the world around them (OECD, 2008). As the world's issues are increasingly of scientific importance; for example, environmental issues, it becomes essential that all members of society need to be scientifically literate (Skamp \& Preston, 2015).

The aims of science education in the New Zealand curriculum document (Ministry of Education [MoE], 2007) mirror the goals reported by the OECD (2008). The key aims of science in the New Zealand curriculum anticipate that students will: develop an understanding of the world; learn the importance and evolving nature of the development and organisation of knowledge in science; and gain and use scientific knowledge and skills to make informed decisions to benefit their own and others' lives and cultures (MoE, 2007). Notwithstanding the well-intentioned purpose of science education internationally, there is a worldwide concern about children's decreasing interest in science as they progress through primary (elementary) school.

Students whose attitudes towards science are negative will become less scientifically literate compared to those with positive science attitudes (Driver, Leach, Millar, \& Scott, 1996). If students do not have positive science experiences in primary school, they will likely endeavour to avoid science in their later education, resulting in an absence of knowledge in and commitment to science (Simpson \& Oliver, 1990). As a consequence, individuals are unlikely to choose science as a career (Jelinek, 1998). Even if children do not want to study science beyond high school, the future advancement of science itself may be affected if future citizens do not recognise its importance (Jenkins \& Nelson, 2005). Furthermore, negative attitudes have unfavourable effects on student achievement (Educational Assessment Research Unit and New Zealand Council for Educational Research [EARU \& NZCER], 2013), and science self-efficacy (Bandura, 1997). It is not surprising then, that there is interest in student attitudes towards science.

\section{Attitude studies internationally and in New Zealand}

Recent research indicates that attitudes can be considered as part of people's belief systems (Jones \& Carter, 2013). However, "attitude" is a construct that has been difficult to define (Tytler, 2014; van Aalderen-Smeets, Walma van der Molen, \& Asma, 2012). In part, this is because the construct of attitude is multidimensional (van Aalderen-Smeets et al., 2012). One of the dimensions of the attitude construct, pertinent to the current study, is the affective dimension (Jones \& Carter, 2013; van Aalderen-Smeets et al., 2012). 
The affective dimension involves feelings related to science, divided into sub-components, both positive and negative. Positive feelings are associated with the enjoyment of science and negative feelings are associated with fear and anxiousness about science. These emotions can occur simultaneously (van Aalderen-Smeets \& Walma van der Molen, 2013). For example, a child can enjoy learning science, yet at the same time experience anxiety about learning science.

Despite the debate around the definition of attitudes, there have been numerous studies regarding children's attitudes towards science. However, much of the past research has focused on students in high school (Silver \& Rushton, 2008). The Relevance of Science Education (ROSE) Project is one such study, which surveyed students' attitudes to school science in their final year of compulsory science across more than forty countries. This study found that school science was more associated with negative attitudes and hence less popular than many other school subjects in all developed countries (Sjøberg \& Schreiner, 2010).

However, students develop their views of science when they are young, and by age 14 their attitude toward science is confirmed and will have an effect on their future career choice (Denessen, Vos, Hasselman, \& Louws, 2015). As a consequence, more recent research has focused on primary science with research on attitudes extending to the primary school (Silver \& Rushton, 2008).

Some research reports positive attitudes to science (e.g., Lal, 2013; Telford \& Caygill, 2007; Tymms, Bolden, \& Merrell, 2008). Others note how student attitudes become less positive over time. Denessen et al. (2015) posited that students develop less positive attitudes toward science during their primary schooling. A similar trend has been noted in New Zealand. The National Education Monitoring Project (NEMP) conducted annual assessments of student achievement, values, and attitudes at Years 4 and 8 (Crooks, Smith, \& Flockton, 2008). While the NEMP results indicate Year 4 and 8 (ages 8 and 12) students are generally very positive about doing science at school, of concern is the drop in the number of Year 8 students who enjoyed science over the various cycles of the NEMP. Additionally, although Year 4 students show more positive attitudes toward science than Year 8 students, all children would like to take part in more science at school (Crooks et al., 2008).

More recently, the National Monitoring Study of Student Achievement (NMSSA) report Science 2012 (EARU \& NZCER, 2013) reported similar findings, with students at Year 4 reporting more positive attitudes to science than at Year 8.

\section{Quantitative and qualitative attitude studies}

Quantitative approaches are commonly used to assess attitudes to science (Koballa \& Glynn, 2013). Such approaches are evident in many of the research studies regarding primary school children's attitudes (e.g., Denessen et al., 2015; Dündar, Guvendir, Kocabiyik, \& Papatga, 2014; Silver \& Rushton, 2008). Attitudinal studies in New Zealand have also used quantitative approaches (e.g., Crooks et al., 2008; EARU \& NZCER, 2013).

Such an approach can 'limit students' responses to pre-defined categories" (Lyons, 2006, p.
593) in order to produce data that can undergo statistical analysis. As Lyons (2006) indicated, "very few studies have taken an interpretive approach to exploring students' reflections on their school science experiences" (p. 592) and as such do not provide the rich descriptions and explanations that qualitative studies can provide (Tytler, 2014).

Given the lack of qualitative studies in New Zealand focused on children's attitudes to science and their experiences of science in the primary classroom, further investigation is warranted. In addition, while research into children's attitudes has been conducted in a number of countries, what is less evident within these studies is evidence of the children's voice. There is a need to find out students' perceptions of science as a subject and to hear their views about their experiences in the classroom. Consequently, in this paper we examine the attitudes of young children towards science as a subject, from their perspective, thereby gaining an in-depth understanding of why a group of children in New Zealand think the way they do.

\section{METHOD}

This article draws on two small-scale studies (described as Study 1 and Study 2 for the purposes of this article). Study 1 examined Year 4 children's attitudes to science in their classroom, while Study 2 examined those of Year 7 children. The intent is not to compare the Year 4 and Year 7 groups, but to use them as illustrative cases or vignettes to highlight the attitudes and experiences of these particular groups. While both studies were conducted separately, they employed a similar methodology and research design. The studies were underpinned by an interpretivist paradigm (Neuman, 2011) that focuses "on the meanings people bring to situations and behaviour, which they use to understand their world" (O'Donoghue, 2007, p.18).

The authors recognise that the sample is small and the situational context is limited to two schools in New Zealand. However, what is significant is that the research provides an opportunity for the children's voices to be heard; thus, allowing the reader to better understand the children's everyday lived experience of the primary school science classroom and the meanings that children make of science within this space (Denzin \& Lincoln, 2000).

\section{School context and participants}

Each study drew its participating children from schools in a large New Zealand city. The school chosen for Study 1 was a primary school and Study 2 involved an intermediate school (upper elementary). A determining factor in choosing the schools was the accessibility of the school to the interviewer and, as such, was a sample of convenience (Punch, 2009). The data was gathered half-way through the school year, so the year groups chosen reflected similar age groups to the previous New Zealand research (Crooks et al., 2008; EARU \& NZCER, 2013).

Permission to carry out the research in each school was given and a pool of possibly participating children was chosen systematically and randomly by a third party from class lists. The parents of the selected students gave their consent and the children assented to take part in an individual, semi-structured interview. 


\section{Data collection and analysis}

In Study 1, six Year 4 children were individually interviewed and in Study 2, five Year 7 children. A semi-structured interview approach was used. The purpose of the individual interviews was to gain information on the children's attitudes towards science and to find out about their experiences in the classroom. This qualitative approach enabled the authors to gather "soft data" on children's attitudes, beliefs, views, emotions, and opinions (Punch, 2009) and to gain an understanding of the individual children's lived experiences of science in the classroom (Creswell, 2013).

Within the semi-structured interview approach, open-ended questions were asked. This approach allowed flexibility, where probing and elaboration on individual answers could occur (Creswell, 2013). The interview questions focused on asking the participants about: their favourite subjects; their experiences with science in the classroom; whether they liked or disliked their science experiences; and, why they felt the way they did about science. The Year 4 students were also asked to comment on various images of scientists. Each individual interview was audio-recorded and field notes were taken to capture non-verbal signs from the children that might enhance the meaning of each child's response. The audio-tapes were subsequently transcribed and pseudonyms are used to provide anonymity.

Data were processed using thematic analysis in which themes were drawn from the data collected. This involved searching for common topics and ideas and through the use of coding and organising data into categories present within the data (Braun \& Clarke, 2006).

\section{FINDINGS AND DISCUSSION}

In general, all the children interviewed were positive about the science they were taught. The Year 4 students were very enthusiastic about it, and two of the Year 4 students, Karen and Karl, stated that science was their favourite subject. In the Year 7 group, all of the students rated science highly, except Jai who was not impressed with theory work or what he described as "boring" topics.

The other students were also able to offer reasons for their enjoyment or aspects of their science learning that dampened their interest. It appears that the students were more engaged when they had a key part to play in the lesson. The students wanted to be taught science that was relevant, to engage in hands-on activities and experience their science learning with others. It also became apparent that the classroom was not the only site for their science learning. These aspects are discussed in turn.

\section{Relevant and meaningful science}

Some of the Year 7 students made real-life connections when discussing their science experiences. Koby described his chosen inquiry project and its application to a real-life context: "If it was actually made then [it] can actually be used ... for hovering cars, ships, and planes." He seemed interested in the effect his scientific ideas could have on life and society. Jai also claimed to "like doing things that are real", because "I like learning about the world." Alanna stated that the main reason she liked science was because "we get to learn about the planet." So, for these students, application to real-life contexts in science made the content more appealing.

The majority of students mentioned that content choice played a part in defining their attitude towards the science experience at hand. Lila, a Year 7 student, spoke enthusiastically about the inquiry project her group did because "we got to choose our own subjects to do a project on....it was really fun." However, in contrast she revealed a time in science when they were learning about "something to do with a tree", complaining "it just wasn't something [children would] think of... at all", and this impacted upon her attitude towards science. Cooper, a Year 7 student, said, "I think it would be better if we get to choose what type of science we could learn." These statements from the children appear to indicate that student-chosen content improved student attitudes towards science.

Year 4 students talked about doing science in groups: the most common activities involved reading and writing. Karl recalled, "We did an explanation on the lifecycle of the butterfly" and "a test on frogs." These children perceived that a strong emphasis was placed on printed media rather than hands-on work. These students did not dislike this work indicating that they, especially the boys, enjoyed reading and writing about science. However, the students wanted to experience hands-on practical activities as well. The majority of Year 4 students were very clear that they liked doing practical work and this made science enjoyable and memorable. Tina stated that doing practical activities "makes me feel really happy" as "you get to guess stuff and then you find out if your answer is correct."

Experiments were mentioned by all Year 7 students, and seemed to play a huge part in whether or not each student enjoyed the science experience. Jai said, "I like experiments... you get to try out new ways to... make it work", and Alanna stated that "I like doing experiments... you have never done them before and it's really, really fun." Cooper thought that if the teacher "let us actually try the experiments more," then his positive attitude towards science would improve.

In addition to practical work, the Year 7 students also talked of learning science through textbook tasks such as, reading, researching, and writing out information. However, this was not their preferred way of learning. Koby concluded that "if you're not doing something to do with practical work then it's not going to be fun." To explain he said, "If you're using a textbook... it's more boring so you won't learn as much." Alanna expressed that she doesn't enjoy "writing about science", as she "sometimes gets bored". Lila saw a need for the theory parts of science because "it leads onto stuff that is quite enjoyable" and that, "You have to do something that is a little bit boring to get into the fun stuff."

\section{Working together}

Group work involved students working together at the same task, and all students from both studies, except Jai, a Year 7 student, cited times when science incorporated group work which they enjoyed. Both Year 4 and Year 7 groups enjoyed group work for both the social aspect and assisting one another in their learning. The Year 4 students were asked to 
comment on various images of scientists. In the picture of scientists working as a team, Tom commented, they "really look like... scientists because they work together and that like me." Tom elaborated that group work was important in order to simulate working like a "real" scientist. For the Year 7 students, group work with an inquiry approach was valued because the students could learn from each other and they found the content enjoyable.

\section{Insufficient science in school}

Interviews with the Year 4 students revealed that they felt the amount of science done at school was unsatisfactory. Sue remarked, "We don't really do that much science and I want to do more;" likewise, Karen wanted to do more science because "we just learn maths, spelling, reading, and stuff like that." For the participants in Study 1 there is a mismatch between the amount of science they would like to do and the amount of science in the classroom. Some of the Year 4 children perceived that the lack of science they were being taught would impact on their future study and careers. Two participants believed they would be unable to pursue science in the future. Tina communicated her apprehension as she stated:

To be a scientist [requires] learning a lot of science in school, but we don't learn a lot but l'd like to. I think [learning] at school would help you to be a scientist and I would be a good scientist but [better] if I learnt some more at school.

Dave also voiced concern as he explained the need to do more science, "so that when I'm older I'm pretty good at science."

\section{Science at home}

While the Year 4 students experienced less science in the classroom than they would like, children reported they engaged in science activities at home. The Year 4 children, particularly the boys, reported that they enjoyed reading non-fiction books about science at home. Karl attributed his perceived ability to having the opportunity to read at home, "I'm pretty good at science because l've got lots of books at home." Conversely, all the Year 4 girls interviewed indicated that their favourite home science activity was experimenting, which aligned with their preference for practical work at school. Karen made a "volcano explosion" and "slime that glows in the dark" which made her feel "proud"-it was the best activity she had ever done. All the girls described feelings of happiness while conducting science experiments at home.

The Year 7 students also indicated they learnt science outside the classroom. Koby's love for science outside school supported his positive attitude to it at school. He revealed, "I... like geology a lot ... I just do it in my own time." His love for geology grew through family holidays travelling to the "Franz Josef Glaciers... experiencing how blue ice could be made." In part, students enjoyed doing science at home because they could pursue their interests. Cooper said, "[Science] outside of school is fun because I get to do what I want," and was "excited" about an experiment he had tried. Lila found her school and home experiences supported each other and professed to "make a lot of stuff at home that I learnt how to do in science." Meanwhile, Jai found it difficult to complete any science at home and stated he liked science within school more because, "the teacher gets to tell you and you get taught...outside I don't [understand]."

\section{Discussion and implications for practice}

By conducting two qualitative studies, the authors uncovered Year 4 and Year 7 children's attitudes towards, and experiences of, science in the classroom. Through Study 1 and Study 2 some of the reasons behind the participants' attitudes to science were uncovered. The children in the current two studies generally had positive attitudes towards science as a subject. However, some of their experiences were less than ideal. The following section discusses the findings and highlights implications for practice.

\section{Addressing students' desire for science}

Despite the concern expressed by researchers, educators, and policy makers of the decreasing interest of young people in science (Meylan, 2010; van Aalderen-Smeets et al., 2012), science is viewed as a low priority subject in primary schools. Research, studies, or reports claim primary school-aged children have minimal exposure to science at school (e.g., Chamberlain \& Caygill, 2012; Mortimer \& Scott, 2000). Mortimer and Scott's (2000) study of 10 primary school classrooms uncovered that only $5 \%$ of total classroom time concerned science. A similar finding has been revealed in New Zealand with an average 52 hours per year of classroom time spent on science (Chamberlain \& Caygill, 2012). The present research reflects these studies, in which it emerged that the Year 4 students, in particular, felt the amount of science done at school was unsatisfactory. Participants in the current study emphasised incongruity between the amount of science that they would like to do at school and the amount actually done.

One of the issues for New Zealand teachers is the expectation they teach across the eight learning areas within the New Zealand curriculum: The Arts, English, Health and Physical Education, Learning Languages, Mathematics and Statistics, Science, Social Sciences, and Technology (MoE, 2007). This may necessitate integrating science with other learning areas such as English which includes learning about reading and writing. This may explain why the Year 4 students discussed the predominance of reading in their science classroom. One cautionary note, however, is that the participants may have been unaware of science teaching that was occurring outside of specific science lessons. Science might, in fact, be more prevalent in the classroom than these students suggest. However, what is clear is that teachers need to be more explicit with students about when science teaching is taking place, particularly when it is integrated with other curriculum areas. Given the crowded curriculum, teachers could take advantage of opportunities to link science learning within the classroom setting to that outside of school and in particular the home environment, particularly since parents can influence student attitudes (Fraser \& Kahle, 2007)

According to Braund and Reiss (2006), incongruity between school science and students' out-of-school science experiences is a common 
educational experience. They described a trend among science educators to de-emphasise the critical influence of out-of-school science experiences on pupils' attitudes towards it. The resultant conundrum faced by teachers is students becoming disinterested in, and forming negative attitudes towards, science at school, while remaining engaged in, and maintaining, positive attitudes at home (Braund \& Reiss, 2006).

Considering the significant time pupils spend outside of formal schooling, it seems prudent that outof-school science contexts and experiences are integrated into the classroom. According to Braund and Reiss (2006), this may result in enhanced student attitudes towards science at school and alleviate the school-home dichotomy.

\section{Relevant content to develop children's attitudes towards science}

While science is not always prioritised, when it is taught, it is often taught from a teacher-centred perspective or taught in ways that are not engaging to children (Blank, 2012). Similar findings have been documented in New Zealand. The NMSSA report (EARU \& NZCER, 2013) stated that both Year 4 and Year 8 students experienced science through listening to their teacher with few opportunities for practical science. These findings indicate that little has changed over time (Crooks et al., 2008; EARU \& NZCER, 2013).

While the children who participated in Study 1 and Study 2 mostly held positive attitudes towards science, it emerged that the context of school science may be neglected to address students' science interests. This could result in deterioration in attitudes towards science, as science at school excludes students' particular interest areas.

In Study 1, though Karen and Karl retained positive attitudes towards science at school, they revealed that the best science activity they had ever done was self-directed and out of school. In Study 2, Jai was the least positive about science, noting that excessive information, boring topics and extreme amounts of reading impacted on his views.

On the other hand, one of the activities that the Year 7 students spoke highly of was an inquiry project. The ability to choose a topic related to their own interests was the key to their enjoyment. As a consequence of the student-driven focus, the children were more engaged and positive about what they were doing. In addition to inquiry work, the children in both studies talked about being more engaged when the work involved practical, hands-on activities. Students' attitudes can be improved when more student-centred approaches are used (Hong, Lin, Wang, Chen \& Yang, 2013) and children deem the content personally relevant (Cowie, Glynn, \& OtrelCass, 2009; Jelinek, 1998). Moreover, it is not surprising that students enjoyed their science at home because they had the opportunity to follow their own interests and engage practically.

While the children in this study are young, their views should not be underestimated when it comes to teachers planning their science lessons. Children's views about topics of interest should be elicited as part of the planning process, both prior to teaching the topic and also once teaching the topic has begun. In addition, teachers could explore students' out-ofschool science endeavours as part of the planning process. In doing so, units of work can be created that incorporate and reflect students' particular science interests and preferred activities. By reframing school science around children's out-ofschool science experiences, teachers are exploiting the substantial influence that students' outside practices have on their attitudes towards science (Braund \& Reiss, 2006).

\section{A sociocultural pedagogy to develop students' positive attitudes towards science}

The findings provide insights into the way in which the children in Study 1 and Study 2 would like to be taught. While the Year 4 students' preferred to work in groups when learning science in school, independent activities such as reading appeared a more common way of learning about science.

Individual conceptual acquisition occurs in social and cultural contexts through participation with others (Leach \& Scott, 2008). Sociocultural views of learning highlight the significance of social interactional processes (Lave \& Wenger, 1991). More interactive learning environments have been found to promote learning and engagement (Areepattamannil, 2012; Sharpe, 2008). From the findings in this study, small changes could be made in the classroom. A sociocultural approach could accommodate students' preferences for group work (Anderson, 2014; Lave \& Wenger, 1991; Lazarowitz \& Hertz-Lazarowitz, 1998) and teachers could respond by developing science units and activities that utilise cooperative learning methods (Lazarowitz \& Hertz-Lazarowitz, 1998). This could accommodate the children's expressed social preference for science work.

\section{CONCLUSION}

The purpose of this article is to examine the attitudes of young children toward science from their perspective, and as such provides an in-depth understanding of why a group of children in New Zealand think the way they do. Findings showed that the children in Study 1 and Study 2 were mostly positive towards science; however, the children wanted to learn more science and study in a learning environment in which they could work together on meaningful topics.

Teachers need to make science a priority in the classroom and change the teaching programme to increase children's exposure to science. While the authors support the call for professional development for teachers (Johnson, Kahle, \& Fargo, 2007), there are also changes that a teacher can make in their classroom on an individual basis.

The authors recognize that primary teachers work within a crowded curriculum. However, it appears there are opportunities to integrate science across a range of learning areas. In addition, teachers can bring out-of-school science learning into the classroom, thereby exposing children to more science as well as creating a collaborative learning environment with the child's family. In both cases however, it is imperative that teachers make explicit to children when science is being taught. Any planning should involve activities that are hands-on and practical and include a social element, while still maintaining aspects that are personally relevant and meaningful to the children. Finding out from children what science topics interest them should be integral to the planning process. What is heartening from 
each of the studies described in this article is the possibility for teachers to create changes in the classroom. Clearly, it is within a teacher's control to take action in order to increase children's interest in science.

\section{REFERENCES}

Anderson, D. (2014). What makes it science? Primary teacher practices that support learning about science. Set: Research Information for Teachers, 2, 9-17.

Areepattamannil, S. (2012) Effects of inquiry-based science instruction on science achievement and interest in science: Evidence from Qatar, The Journal of Educational Research, 105(2), 134146. DOI: $10.1080 / 00220671.2010 .533717$

Bandura, A. (1997). Self-efficacy: The exercise of control. New York, NY: Freeman.

Blank, R. K. (2012). What is the impact of decline in science instructional time in elementary school? Paper prepared for the Noyce Foundation. Retrieved from http://www.csssscience.org/downloads/NAEPElemScienceData .pdf

Braun, V., \& Clarke, V. (2006). Using thematic analysis in psychology. Qualitative Research in Psychology, 3(2), 77-101. DOI: 10.1191/1478088706qp063oa

Braund, M., \& Reiss, M. (2006). Towards a more authentic science curriculum: The contribution of out-of-school learning. International Journal of Science Education, 28(2), 1373-1388. DOI: $10.1080 / 09500690500498419$

Chamberlain, M., \& Caygill, R. (2012). Key findings from New Zealand's participation in the Progress in International Reading Literacy Study (PIRLS) and Trends in International Mathematics and Science Study (TIMSS) in 2010/11.

Cowie, B., Glynn, T., \& Otrel-Cass, K. (2009). Let it rip-Patero at its best! Set: Research Information for Teachers, 11(3), 29-35.

Creswell, J. W. (2013). Research design: Qualitative, quantitative, and mixed methods approaches. Thousand Oaks, CA: Sage.

Crooks, T., Smith, J., \& Flockton, L. (2008). National education monitoring project. Science assessment results 2007. Wellington, New Zealand: Ministry of Education.

Denessen, E., Vos, N., Hasselman, F., \& Louws, M. (2015). The relationship between primary school teacher and student attitudes towards science and technology. Education Research International, 2015, Article ID 534690 Retrieved from

http://www.hindawi.com/journals/edri/2015/5346 90/

Denzin, N. K., \& Lincoln, Y. S. (2000). The discipline and practice of qualitative research. In N. K. Denzin \& Y. S. Lincoln (eds.). Handbook of qualitative research $\left(2^{\text {nd }}\right.$ ed., pp. 1-45). Thousand Oaks, CA: Sage.

Driver, R., Leach, J., Millar, R., \& Scott, P. (1996). Young people's images of science. Buckingham, England: Open University Press

Dündar, S., Güvendir, M., Kocabiyik, O., \& Papatga E. (2014). Which elementary school subjects are the most likeable, most important, and the easiest? Why?: A study of science and technology, mathematics, social studies, and Turkish. Educational Research and Reviews, 9(13), 417-428.

Educational Assessment Research Unit and New Zealand Council for Educational Research. (2013). Wānangatia te putanga tauira: National monitoring study of student achievement, science 2012. Wellington, New Zealand: Ministry of Education.

Fraser, B. \& Kahle, J. (2007). Classroom, home and peer environment influences on student outcomes in science and mathematics. An analysis of systematic reform data. International Journal of Science Education, 29(15), 18911909.

Hong, Z., Lin, H., Wang, H., Chen, H. \& Yang, K. (2013). Promoting and scaffolding elementary school students' attitudes toward science and argumentation through a science and society intervention. International Journal of Science Education, 35(10), 1625-1648. DOI: 10.1080/09500693.2012.734935.

Jelinek, J. (1998, April). Student perceptions of the nature of science and attitudes towards science education in an experiential science program. Paper presented at the Annual Meeting of the National Association for Research in Science Teaching, San Diego, California.

Jenkins, E. W., \& Nelson, N. W. (2005). Important but not for me: Students' attitudes towards secondary school science in England. Research in Science \& Technological Education, 23(1), 41-57. DOI: 10.1080/02635140500068435

Johnson, C. C., Kahle, J. B. \& Fargo, J. D. (2007). A study of the effect of sustained, whole-school professional development on student achievement in science. Journal of Research in Science Teaching, 44(6), 775-786. DOI:10.1002/tea.20149

Jones, G., \& Carter, G. (2013). Science teacher attitudes and beliefs. In M. Talbot-Smith, K. Appleton, \& D. Hanuscin (Eds.). Handbook of research on science education (pp. 1067-1104). Mahwah: Taylor and Francis.

Koballa, T. \& Glynn, S. (2013). Attitudinal and motivational constructs in science learning. In M. Talbot-Smith, K. Appleton, \& D. Hanuscin (Eds.). Handbook of research on science education (pp. 75-102). Mahwah: Taylor and Francis.

Lal, K. (2013). What are the attitudes of our year six students towards science? (Unpublished dissertation), Faculty of Education, The University of Auckland.

Lave, J., \& Wenger, E. (1991). Situated learning: Legitimate peripheral participation. Cambridge, England: Cambridge University Press.

Lazarowitz, R., \& Hertz-Lazarowitz, R. (1998). Cooperative learning in science curriculum. In B. Fraser \& K. G. Tobin (eds.), International handbook of science education (pp. 449-471). Netherlands: Kluwer Academic.

Leach, J., \& Scott, P. (2008). Teaching for conceptual understanding: An approach drawing on individual and sociocultural perspectives. In S Vosniadou (Ed.), International handbook of research on conceptual change (pp. 647-675). New York, NY: Routledge. 
Lyons, T. (2006). Different countries, same science classes: Students' experiences of school science in their own words. International Journal of Science Education, 28(6), 591-613. DOI:10.1080/09500690500339621

Meylan, R. (2010). Advancing primary science. New Zealand Science Teacher, 125, 44-45.

Ministry of Education. (2007). The New Zealand curriculum. Wellington, New Zealand: Learning Media.

Mortimer, E. F., \& Scott, P. H. (2000). Analysing discourse in the science classroom. In J. Leach, R. Millar, \& J. Osborne (Eds.), Improving science education: The contribution of research (pp. 126-142). Milton Keynes, England: Open University Press.

Neuman, W. (2011). Social research methods: Qualitative and quantitative approaches $\left(7^{\text {th }}\right.$ ed.). Boston, MA: Allyn \& Bacon.

O'Donoghue, T. (2007). Planning your qualitative research project: An introduction to interpretivist research in education. London, England: Routledge.

OECD. (2007). PISA 2006 science competencies for tomorrow's world: Executive summary. Paris, France: Author.

OECD. (2008). Encouraging student interest in science and technology studies. Paris, France: Author.

Osborne, J. (2007). Science education for the twenty first century. Eurasia Journal of Mathematics, Science \& Technology, 3(3), 173-184.

Punch, K. (2009). Introduction to research methods in education. London, England: Sage.

Sharpe, T. (2008). How can teacher talk support learning? Linguistics and Education, 19, 132148.

Silver, A., \& Rushton, B. (2008). Primary-school children's attitudes towards science, engineering and technology and their images of scientists and engineers. Education, 51-57.
Simpson, R. D. \& Oliver, J. S. (1990). A summary of major influences on attitudes toward and achievement in science among adolescent students. Science Education, 74, 1-18. DOI: 10.1002/sce.3730740102

Sjøberg, S., \& Schreiner, C. (2010). The ROSE project. An overview and key findings. Retrieved from

http://roseproject.no/network/countries/norway/e ng/nor-Sjoberg-Schreiner-overview-2010.pdf

Skamp. K., \& Preston, C. (2015). Teaching primary science constructively ( $5^{\text {th }}$ ed.). Melbourne, Australia: Cengage Learning.

Telford, M., \& Caygill, R. (2007). PISA 2006: How ready are our 15-year-olds for tomorrow's world? Wellington, New Zealand: Comparative Education Research Unit.

Tymms, P., Bolden, D., \& Merrell, C. (2008). Science in English primary schools: Trends in attainment, attitudes and approaches. Perspectives on Education: Primary Education, 1, 19-43.

Tytler, R. (2014). Attitudes, identity, and aspirations toward science. In N. G. Lederman \& S. K. Abell (Eds.), Handbook of research on science education (pp. 82-103). New York, NY: Routledge.

van Aalderen-Smeets, S. I., \& Walma van der Molen, J. H. (2013). Measuring primary teachers' attitudes toward teaching science: Development of the dimensions of attitude toward science (DAS) instrument. International journal of science education, 35(4), 577-600.

van Aalderen-Smeets, S. I., Walma van der Molen, J. H. \& Asma, L. J. F. (2012). Primary teachers' attitudes toward science: A new theoretical framework. Science Education, 96(1), 158-182. DOI: $10.1002 /$ sce.20467 